\title{
Effects of Pentachlorophenol, Pentylenetetrazol and Carnitine on Mitochondria
}

\author{
Zhengping YU, Yoshihisa IRYo, Masato MATsuOKA and Hideki IGISU \\ Department of Environmental Toxicology, Institute of Industrial Ecological Sciences, \\ University of Occupational and Environmental Health, Japan. \\ Yahatanishi-ku, Kitakyushu 807-8555, Japan
}

Abstract: Pentachlorophenol (PCP) increased oxygen consumption and lowered the respiratory control ratio (RCR) in mitochondria from rat liver. These effects of PCP were lessened by $1 \mathrm{mM}$ L-carnitine but not by D-carnitine. In contrast, up to $150 \mathrm{mM}$ of pentylenetetrazol (PTZ) added at state 4 of respiration did not accelerate oxygen consumption. When mitochondria were incubated with $3.3 \mathrm{mM}$ of PTZ, oxygen consumption, $\mathrm{RCR}$ and $\mathrm{ADP} / \mathrm{O}$ ratio were all decreased. Moreover, these could not be suppressed even by high concentrations ( $-20 \mathrm{mM})$ of L-carnitine. Thus, while L-carnitine could suppress effects of PCP, it could not counteract PTZ in mitochondria. It appears that anticonvulsive effects of carnitine in PTZ-induced seizures may not be due to mitochondrial protection.

Key words pentachlorophenol, pentylenetetrazol, carnitine, seizure, anticonvulsive.

(Received 17 August 1998, accepted 30 September 1998)

\section{Introduction}

Carnitine ( $\beta$-hydroxy- $\gamma$-N-trimethylbutyrate) is widely distributed among tissues including the brain. In extraneural tissues, carnitine is an essential cofactor for the transport of fatty acids through the inner mitochondrial membrane [1]. In the brain, however, fatty acids are not utilized as an energy source, and physiological functions of carnitine are unknown. Previous studies have indicated that carnitine can protect the brain from various insults such as hyperammonemia $[2,3]$ and severe ischemia [4]. We have observed that carnitine can also suppress convulsions induced by pentylenetetrazol (PTZ) [5], which is one of the most commonly used epileptogenic agents. However, its mechanism is not clear. We therefore examined effects of PTZ and carnitine on mitochondria comparing them with those of pentachlorophenol (PCP) [6-8] which is a typical chemical that impairs biological membranes including mitochondria. 


\section{Materials and Methods}

Chemicals: L-Carnitine (inner salt), D-carnitine (inner salt), pentachlorophenol (PGP) and pentylenetetrazol (P'TZ) were purchased from Sigma (St. Louis, Mo). All other chemicals were reagent grade.

Mitochondria: Livers from male Wistar rats were minced quickly in a solution containing $250 \mathrm{mM}$ sucrose, $0.5 \mathrm{mM}$ EDTA and $10 \mathrm{mM}$ Tris-HCl (pH 7.4), and homogenized in a Potter-Elvehjem homogenizer with a teflon pestle. The homogenate was centrifuged at $800 \times \mathrm{g}$ for 10 min to obtain supernatant, which was then centrifuged at $10000 \times \mathrm{g}$ for $8 \mathrm{~min}$. After the sediment was resuspended in the solution and centrifuged at $8000 \times \mathrm{g}$ for $8 \mathrm{~min}$, the supernatant was discarded. These procedures were all done at $4^{\circ} \mathrm{C}$. Protein of the mitochondiral suspension was determined by the method of Lowry et al [9].

Oxygen consumption: The solution used to measure oxygen consumption $(3 \mathrm{ml})$ contained $225 \mathrm{mM}$ sucrose, $10 \mathrm{mM} \mathrm{KGl,} 5 \mathrm{mM} \mathrm{MgCl} 2,5 \mathrm{mM}$ potassium phosphate buffer ( $\mathrm{pH}$ 7.4), $0.5 \mathrm{mM}$ EDTA, $20 \mathrm{mM}$ Tris-HCl $(\mathrm{pH} \mathrm{7.4)}$ and mitochondrial suspension (4.5 mg of protein). A YSI Model 5300 Biological Oxygen Monitor (Yellow Spring Instrument, Yellow Spring, Ohio) equipped with a Clark-type oxygen electrode was used and the changes were recorded with a Hitachi 056 recorder. The temperature of the reaction mixture $\left(30^{\circ} \mathrm{C}\right)$ was controlled with a Lauda RM3 high precision circulating water bath (LaudaKöningshofen). Unless otherwise stated, mitochondrial suspension was first incubated with or without carnitine ( $\mathrm{I}$ or $\mathrm{D}$-form) for $10 \mathrm{~min}$ at $30^{\circ} \mathrm{C}$, and then with or without a chemical (PCP or PTZ) for another $10 \mathrm{~min}$. The reaction was monitored after adding $5 \mu \mathrm{l}$ of $80 \mathrm{mM} \mathrm{ADP}$ and $10 \mu \mathrm{l}$ of $200 \mathrm{mM} \alpha$-ketoglutarate. When necessary, chemicals were added through the port of the reaction chamber. PCP was first dissolved in ethanol and then added to the reaction mixture. The final concentration of ethanol was less than $0.3 \%$ which did not affect the reaction.

The respiratory control ratio (RGR) was calculated as (oxygen consumption at state 3 of respiration)/(oxygen consumption at state 4$)$, and $\mathrm{ADP} / \mathrm{O}$ ratio as (ADP added)/(oxygen consumed).

\section{Results}

PCP dose-dependently increased oxygen consumption and lowered RCR (Fig. 1). These changes were less marked when $1 \mathrm{mM}$ L-carnitine was present. In addition, L-carnitine dose-dependently suppressed effects of PCP while Dcarnitine did not (Fig. 2). 

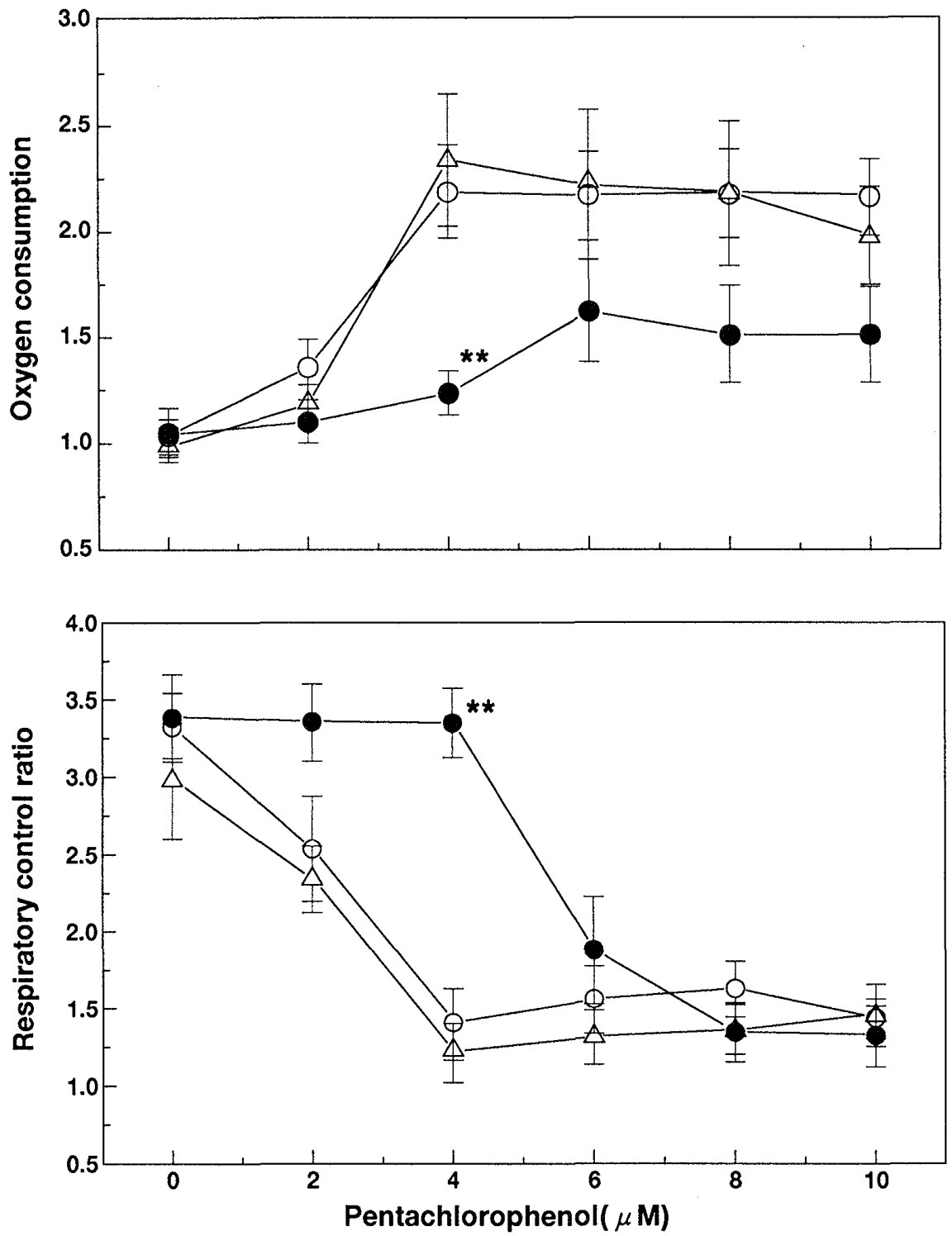

Fig. 1. Effects of pentachlorophenol (PCP) and l-carnitine on oxygen consumption and respiratory control ratio $(\mathrm{RCR})$ in mitochondria from rat liver (Mean $\pm \mathrm{SE}, \mathrm{n}=6$ ). Mitochondria were incubated with PGP and $\mathrm{L}$-carnitine $(1 \mu \mathrm{M}$ or $1 \mathrm{mM})$ or without it for $10 \mathrm{~min}$ at $30^{\circ} \mathrm{C}$, and changes in the amount of oxygen in the solution were monitored. Oxygen consumption is expressed as nmol oxygen consumed $/ \mathrm{mg}$ protein $/ \mathrm{min}$. Asterisks indicate differences from the control (no carnitine) $\left({ }^{*} P<0.01\right.$, by Student $t$-test).

- No Carnitine, $-\triangle-1_{\mu} \mathrm{M}$ L-Carnitine, - $1 \mathrm{mM}$ L-Carnitine

On adding P'TZ to the reaction mixture successively over a wide range of concentrations $(3,6,9,12$ and $15 \mu \mathrm{M} ; 30,60,90,120$ and $150 \mu \mathrm{M} ; 3,6,9,12$ and $15 \mathrm{mM} ; 30,60,90,120$ and $150 \mathrm{mM}$ ) at state 4 of respiration, no increase of oxygen consumption was observed. When mitochondira were incubated with $3.3 \mathrm{mM}$ of PTZ for 10min, oxygen consumption, $\mathrm{RGR}$ and $\mathrm{ADP} / \mathrm{O}$ ratios were all decreased (Fig. 3). L-Carnitine even at $20 \mathrm{mM}$ did not suppress these effects of PTZ (Fig. 4). 

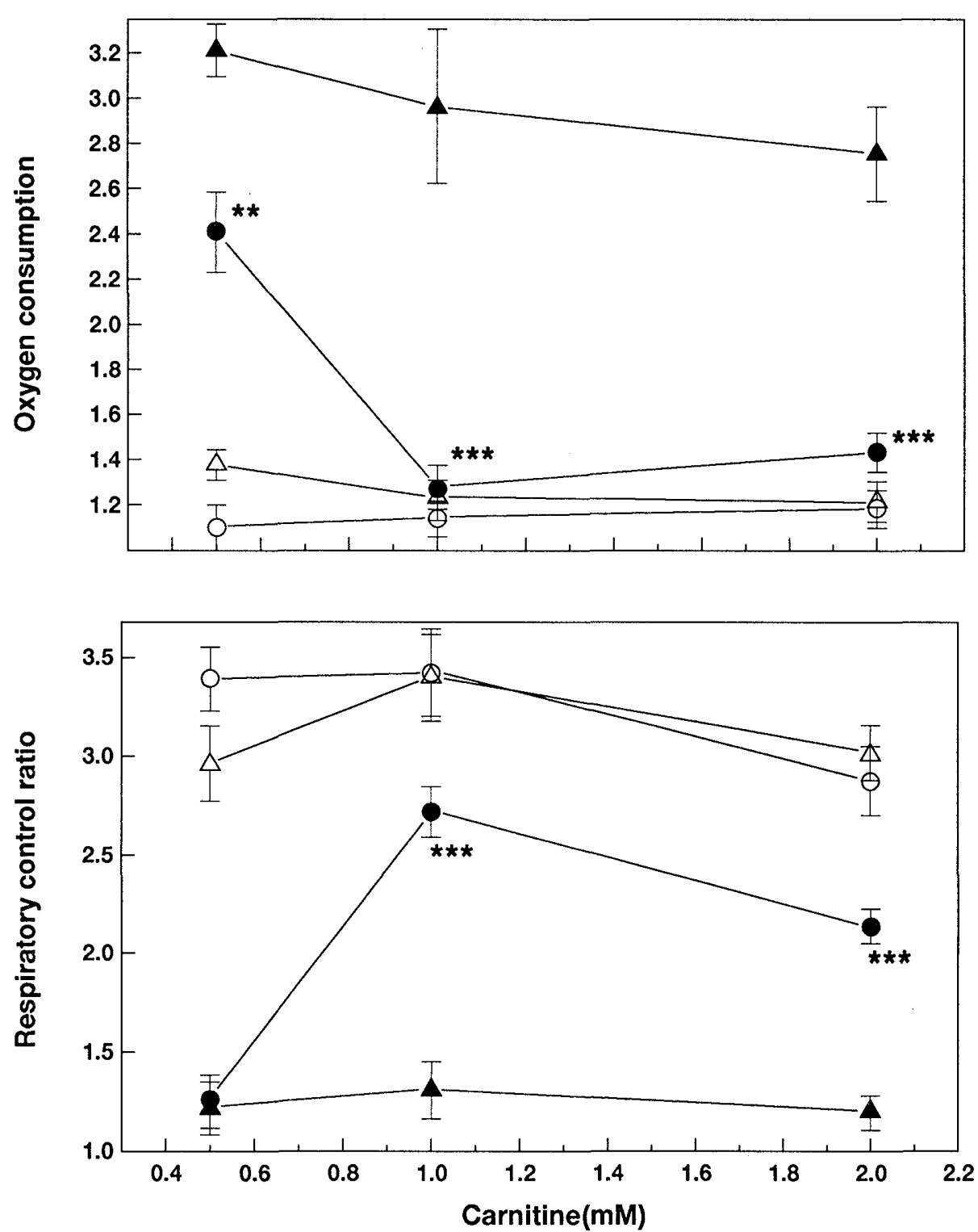

Fig. 2. Effects of $\mathrm{L}$ - and 1)-carnitine on pentachlorophenol (PCP)-induced alterations of oxygen consumption and respiratory control ratio (RCR) in mitochondria from rat liver (Mean $\pm \mathrm{SE}, \mathrm{n}=6$ ). Mitochondria were incubated with carnitine ( $\mathrm{L}$ - and $\mathrm{D}$-form) for 10 min at $30^{\circ} \mathrm{C}$ and then with PCP $(3 \mu \mathrm{M})$ or without it for 10 min and changes in oxygen consumption in the solution were monitored. Asterisks indicate difference from the effect of $\mathrm{D}$-carnitinc $\left(* * P<0.01,{ }^{* * *} P<0.001\right.$, by Student $t$-test).

$$
\begin{aligned}
& -\mathrm{O} \text { - No PCP + L-Carnitine, }--3_{\mu} \mathrm{M} P \mathrm{PCP}+\mathrm{L} \text {-Carnitine } \\
& -\triangle-\text { No PCP + D-Carnitine, }-\mathbf{\Delta}-3_{\mu} \mathrm{M} \text { PCP + D-Carnitine }
\end{aligned}
$$




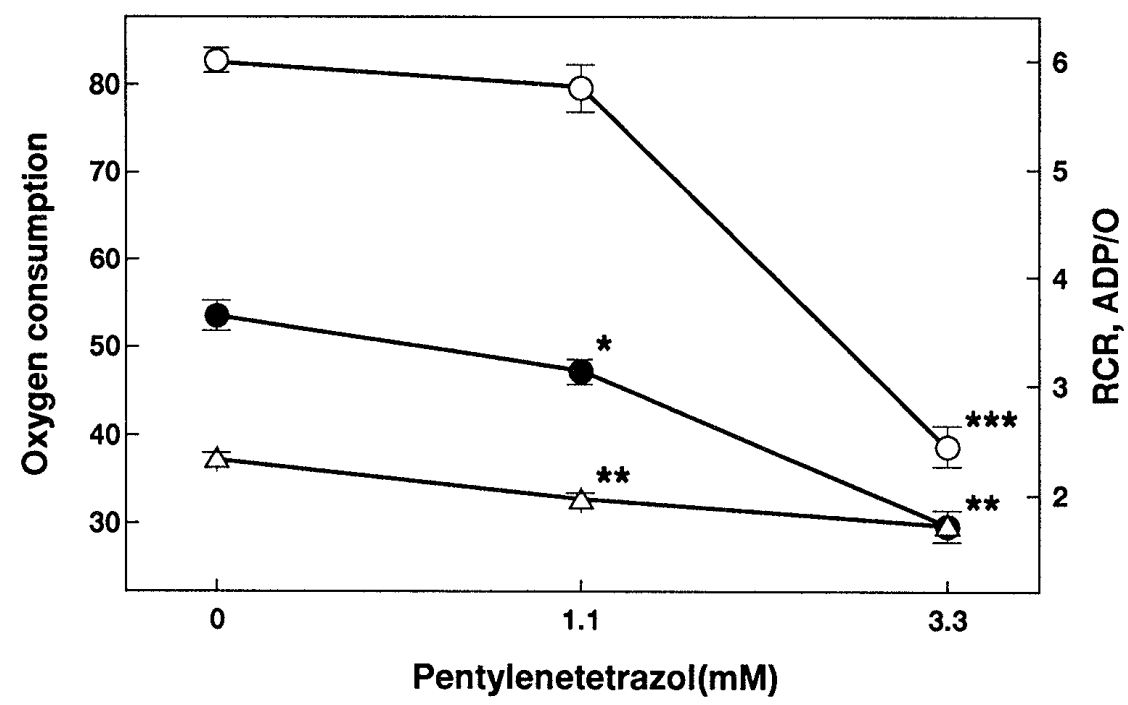

Fig. 3. Effects of pentylenetetrazol (PTZ) on oxygen consumption, respiratory control ratio $(\mathrm{RGR})$ and $\mathrm{ADP} / \mathrm{O}$ ratio in mitochondria from rat liver (Mean $\pm \mathrm{SE}, \mathrm{n}=6$ ). After mitochondria were incubated with PTZ or without it for 10 min at $30^{\circ} \mathrm{C}, \mathrm{ADP}$ and $\alpha$ ketoglutarate were added and the amount of oxygen in the solution were measured. Asterisks indicate difference from the control (without PTZ) $\left({ }^{*} P<0.05,{ }^{* *} P<0.01\right.$, ${ }^{* * *} P<0.001$, by Student $t$-test).

$-\mathrm{O}-\mathrm{O}_{2}$ consumption, $-\mathrm{RCR},-\triangle-\mathrm{ADP} / \mathrm{O}$

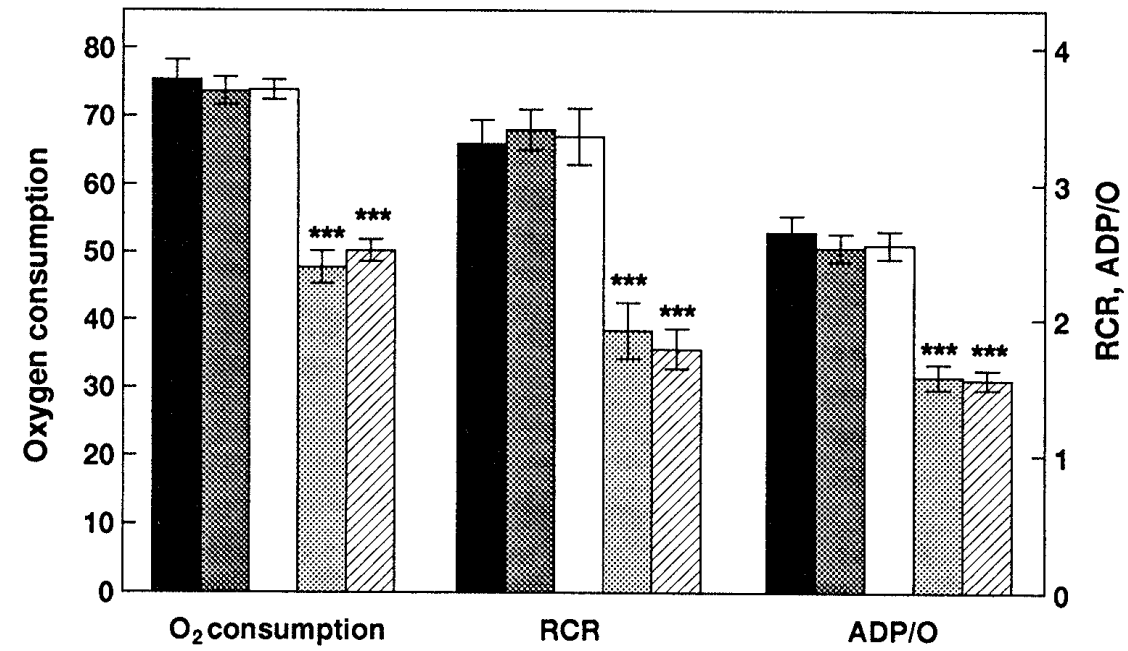

Fig. 4. Effects of pentylenetetrazol (PTZ) and L-carnitine on oxygen consumption, respiratory control ratio (RCR) and $\mathrm{ADP} / \mathrm{O}$ ratio in mitochondria from rat liver (Mean $\pm \mathrm{SE}$, $\mathrm{n}=6$ ). After mitochondria were incubated with PTZ and L-carnitine for $10 \mathrm{~min}$ at $30^{\circ} \mathrm{C}$, the reaction was started by adding ADP and $\alpha$-ketoglutarate. Similar results were obtained when mitochondria were first incubated with $\mathrm{L}$-carnitine ( 2 and $10 \mathrm{mM}$ ) at $30^{\circ} \mathrm{C}$ for $10 \mathrm{~min}$ and then for another $10 \mathrm{~min}$ with PTZ $(3.3 \mathrm{mM})$. Asterisks indicate differences from the control (without PTZ and carnitine) $\left({ }^{* *} P<0.001\right.$, by Student $t$-test).

control, $10 \mathrm{mM}$ L-Carnitine, 3.3mM PTP + 10mM L-Carnitine,
$20 \mathrm{mM}$ L-Carnitine,

3.3mM PTP $+20 \mathrm{mM}$ L-Carnitine, 


\section{Discussion}

Although PCP has been used widely, it can be toxic to humans and even fatal cases of intoxication with PCP have been reported [7]. The mechanisms of the toxicity have not been fully clarified but PGP has been known to disrupt biological membranes including mitochondria and erythrocyte membrane; PCP is a potent uncoupler of oxidative phosphorylation in mitochondria [6], and it can hemolyze erythrocytes [7]. The increase of oxygen consumption and decrease of RCR in mitochondria seen in the present experiments are consistent with the uncoupling of oxydative phosphorylation by PCP. And these could be suppressed by Lcarnitine. This indicates that L-carnitine can protect mitochondria not only in hyperammonemia [10] or damage induced by octanoic acid [11] but also from impairment caused by PCP. Hence, it is of interest that mitochondrial dysfunction caused by different kinds of chemicals can be ameliorated by Lcarnitine which plays an important physiological role in the inner mitochondrial membrane. Furthermore, it is also of interest that, in the case of PCP as seen in the present experiments, only L-carnitine exerted protective effects, while Dcarnitine did not because D-carnitine is believed not to occur naturally and has been shown to interfere with some effects of L-carnitine [12]. However, much more work is necessary before any conclusion can be drawn concerning whether carnitine is effective in the prevention or treatment of intoxication with PCP.

PTZ is one of the most commonly used epiletogenic agents to evaluate possible anticonvulsive drugs. Although the mechanism of epileptogenesis by PTZ has not been well understood, drugs effective in suppressing PTZ-induced seizures often affect GABAergic systems [13]. On the other hand, it has been reported that GABA caused swelling of mitochondria in vitro [14]. Furthermore, ATP content in the brain decreased prior to convulsions induced by chemicals including PTZ [15]. We previously observed that L-carnitine could also suppress seizures induced by PTZ as well as alterations of high energy phosphate compounds in the brain in mice [5]. Hence, it would be of interest to examine effects of PTZ and carnitine on mitochondria in vitro, particularly because the mechanism of the anticonvulsive effects of carnitine is unclear, and because the protective effects of carnitine on mitochondria have been suggested in ammonium intoxication and in octanoic acid-induced brain damage $[10,11]$. Nevertheless, we observed no changes indicating that PTZ uncoupled oxidative phosphorylation in mitochondria i.e. we saw no increase of oxygen consumption by PTZ. But we did observe that PTZ could impair mitochondrial functions; oxygen consumption, RCR and ADP/O ratio were lowered by PTZ. However, these effects of PTZ are most likely nonspecific because only high concentrations of 
PTZ could induce them and because all indices were lowered. Furthermore, while toxicities of PGP could be suppressed by L-carnitine, no protection against PTZ toxicities were provided by L-carnitine, even at high concentrations. Thus, at least in vitro, while L-carnitine could suppress effects of PCP, it did not show any protective effects on mitochondria from PTZ. Hence, it is likely that the anticonvulsive effects of carnitine in PTZ-induced seizures may not be due to mitochondrial protection.

\section{Acknowledgments}

This study was supported in part by a grant-in-aid from the Ministry of Education, Science, Sports and Culture, Japan. Zhengping Yu was a visiting scientist at our Department and supported by the Sasakawa Fellowship.

\section{References}

1. Igisu H, Matsuoka M \& Iryo Y (1995): Protection of the brain by carnitine. J Occup Health 37: $75-82$

2. Matsuoka M, Igisu H, Kohriyama K \& Inoue N (1991): Suppression of neurotoxicity of ammonia by L-carnitine. Brain Res 567: 328-331

3. Matsuoka M \& Igisu H (1993): Comparison of the effects of L-carnitine, D-carnitine and acetylL-carnitine on the neurotoxicity of ammonia. Biochem Pharmacol 46: 159-164

4. Matsuoka M \& Igisu H (1992): Preservation of energy metabolites by carnitine in the mouse brain under ischemia. Brain Res 590: 334-336

5. Yu ZP, Iryo Y, Matsuoka M, Igisu H \& Ikeda M (1997): Suppression of pentylenetetrazolinduced seizures by carnitine in mice. Naunyn-Schmiedeberg's Arch Pharmacol 355: $545-549$

6. Weinbach EC (1954): The effect of pentachlorophenol on oxidative phosphorylation. J Biol Chem 210: $545-550$

7. Igisu H (1993): Haemolysis of human erythrocytes by pentachlorophenol and its suppression by albumin. Br J Ind Med 50: 378-379

8. Igisu H, Hamasaki N \& Ikeda M (1993): Highly cooperative inhibition of acetylcholinesterase by pentachlorophenol in human erythrocytes. Biochem Pharmacol 46: 175-177

9. Lowry OH, Rosebrough NJ, Farr AL \& Randall RJ (1951): Protein measurement with the Folin phenol reagent. J Biol Chem 193: 265-275

10. Bobyleva-Guarriero V, Di Lisa F, Iannone A \& Siliprandi N (1985): Ameliorating effect of carnitine on liver mitochondria functions in ammonium intoxicated rats. IRCS Med Sci 13: $399-400$

11. Kim C.S, Roe GR \& Ambrose WW (1990): L-Carnitine prevents mitochondrial damage induced by octanoic acid in the rat choroid plexus. Brain Res 536: 335-338

12. Fritz IB \& Schultz SK (1965): Carnitine acetyltransferase. II. Inhibition by carnitine analogues and by sulfhydryl reagents. J Biol Chem 240: 2188-2192

13. Rogawski MA \& Porter RJ (1990): Antiepileptic drugs: pharmacological mechanisms and clinical efficacy with consideration of promising developmental stage compounds. Pharmacol Rev 42: 223-286 
14. Marczynski TJ (1998): GABAergic deafferentation hypothesis of brain aging and Alzheimer's disease revisited. Brain Res Bull 45: 341-379

15. Sanders AP, Kramer RS, Woodhall B \& Currie WD (1970): Brain adenosine triphosphate: decreased concentration precedes convulsions. Science 169: 206-208

ペンタクロロフェノール， ペンチレンテトラゾール，カルニチンの

ミトコンドリアへの影響

余争平，井料 佳久，松岡 雅人，伊規須英輝

産業医科大学産業生態科学研究所 環境中毒学教室

要 旨： ペンタクロロフェノール (PCP) は，ラット肝臓より得たミトコンドリアで酸素消費 増加と呼吸調節比（RCR）低下をもたらした。これらの PCP の効果は， $1 \mathrm{mM}$ の L-力 ルニチンによって抑制されたが，D-カルニチンは無効であった。これと対照的に， ペンチレンテトラゾール (PTZ) は，状態 4 呼吸時に $150 \mathrm{mM}$ まで加えても，酸素消 費を元進させなかった。ミトコンドリアを $3.3 \mathrm{mM}$ の PTZ とインキュベートすると， 酸素消費，RCR，ADP/O 比いずれも低下した。しかも，これらは高濃度 $(20 \mathrm{mM}$ 以 下）のL-カルニチンによって抑制され得なかった。すなわち，Lーカルニチンは PCP の影響に対しては明確な保護効果を示したが, PTZ の作用からミトコンドリアを保 護することはなかった．PTZ誘発けいれんにおけるカルニチンの抗けいれん作用は， ミトコンドリア保護によるのではない可能性が考えられる.

J UOEH（産業医大誌）20(4)：315-322（1998) 